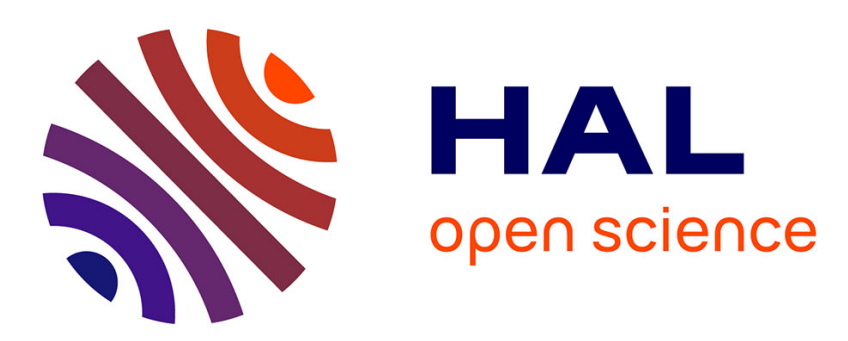

\title{
Implications of continuous structural inversion in the West Netherlands Basin for understanding controls on Palaeogene deformation in NW Europe
} Geza Worum, Laurent Michon

\section{- To cite this version:}

Geza Worum, Laurent Michon. Implications of continuous structural inversion in the West Netherlands Basin for understanding controls on Palaeogene deformation in NW Europe. Journal of the Geological Society of London, 2005, 162, pp.73-85. 10.1144/0016-764904-011 . hal-01382031

\section{HAL Id: hal-01382031 \\ https://hal.univ-reunion.fr/hal-01382031}

Submitted on 4 Nov 2016

HAL is a multi-disciplinary open access archive for the deposit and dissemination of scientific research documents, whether they are published or not. The documents may come from teaching and research institutions in France or abroad, or from public or private research centers.
L'archive ouverte pluridisciplinaire HAL, est destinée au dépôt et à la diffusion de documents scientifiques de niveau recherche, publiés ou non, émanant des établissements d'enseignement et de recherche français ou étrangers, des laboratoires publics ou privés. 


\title{
Implications of continuous structural inversion in the West Netherlands Basin for understanding controls on Palaeogene deformation in NW Europe
}

\author{
GEZA WORUM ${ }^{1}$ \& LAURENT MICHON ${ }^{2,3}$ \\ ${ }^{1}$ Department of Tectonics, Vrije Universiteit, De Boelelaan 1085, 1081 HV Amsterdam, The Netherlands \\ (e-mail:worg@geo.vu.nl) \\ ${ }^{2}$ Department of Geoenergy, TNO-NITG, Princetonlaan 6, 3508 TA Utrecht, The Netherlands \\ ${ }^{3}$ Present address: Laboratoire des Sciences de la Terre, Université de la Réunion, 15 rue René Cassin, 97715 Saint Denis \\ cedex 9, Paris, France
}

\begin{abstract}
A detailed analysis of high-quality 3D seismic and borehole data provides new insights into the Palaeogene tectonic history and inversion of the West Netherlands Basin. The inversion characteristics are compared with those of other basins in the region, to provide constraints on the Palaeogene compressional tectonic movements in NW Europe. The inversion of the West Netherlands Basin, which is characterized by the doming of the basin centre and by the reactivation of pre-existing faults in a reverse mode, was found to be the result of a continuous inversion process rather than a distinct tectonic pulse. The intensity of the tectonic movements was not uniform throughout the Eocene and was strongest during the Latest Eocene. These characteristics are similar to those of other basins in the southern North Sea region and in the English Channel area. In addition, a good correlation exists between Alpine tectonic events and the Palaeogene inversion phases. In light of these observations the Latest Eocene inversion pulse in the southern North Sea region can be considered as the culmination of a long-term inversion process that originated from the Alpine collision.
\end{abstract}

Keywords: tectonics, sedimentation, erosion, basin analysis.

It has been long recognized that basin subsidence in various Mesozoic basins located in Central and NW Europe was terminated in the Late Cretaceous and was followed by basin inversion (see Ziegler 1987, for summary). Detailed analysis of the deformation as well as the main erosion events in these basins suggests that the inversion occurred in four major phases (the Late Cretaceous (c. Santonian), the Mid-Palaeocene, the Late Eocene-Early Oligocene and the Late Oligocene-Early Miocene phases). However, there are indications from several inverted areas that (1) one particular inversion phase can take considerable time and (2) the time interval between two subsequent inversion phases is tectonically not quiet but is often represented by continued, calmer tectonic movements (e.g. Jones 1980; Van Hoorn 1987; Curry 1992; Vågnes et al. 1998; Gras \& Geluk 1999). In this paper a contribution is made to the characterization and understanding of the Late Eocene inversion process in the southern North Sea area by presenting a case study from the West Netherlands Basin.

The West Netherlands Basin is situated in the southern North Sea Basin and adjacent onshore parts of the Netherlands (Fig. 1a). Together with other sedimentary basins in the area (Roer Valley Graben, Central Netherlands Basin, Broad Fourteens Basin, Sole Pit Basin), it developed in response to multiple rifting phases during the Late Palaeozoic-Mesozoic period (e.g. Heybroek 1974; Van Wijhe 1987; Ziegler 1990; Dronkers \& Mrozek 1991). In response to subsequent inversion phases, preexisting normal faults were reactivated in a transpressional manner (e.g. De Jager et al. 1996; Racero-Baena \& Drake 1996) resulting in the deformation and uplift of the basin fill as well as its subsequent erosion. All four above-mentioned tectonic phases are recognized in the West Netherlands Basin. Of these the Late Cretaceous and Mid-Palaeocene phases were the strongest, whereas the Late Oligocene phase was very gentle and is represented only by a regional unconformity.

The Late Palaeocene-Eocene geological history of the West Netherlands Basin is markedly different from the Mesozoic evolution. Following the Mid-Palaeocene inversion phase the West Netherlands Basin ceased to exist as a major depocentre and became a tectonic high called the Early Tertiary High (also known as the Kijkduin high) (Fig. 1a). The sedimentary record indicates that the main depocentres (Voorne Trough, Zuiderzee Low) were located north and south of the West Netherlands Basin (e.g. Heybroek 1974; Letsch \& Sissingh 1983; Zagwijn 1989; Van Adrichem Boogaert \& Kouwe 1997; TNO-NITG 2002). The Eocene evolution of the Early Tertiary High is poorly known, as the Late Palaeocene-Eocene sedimentary record was partly or totally removed during the Late Eocene tectonic movements. It is suggested, however, that on the Early Tertiary High only a small amount of sediments was deposited during the Eocene.

Considering the amount of deformation and erosion, the Late Eocene tectonic phase in the West Netherlands Basin and in other basins of the southern North Sea region is of secondary importance compared with the Late Cretaceous inversion (e.g. Van Hoorn 1987; Ziegler 1987; De Lugt et al. 2003). Because of this a detailed analysis of the preserved Palaeogene sediments is possible, which can help us to characterize and better understand the Late Eocene tectonic movements in the southern North Sea region and can also provide useful constraints on synsedimentary inversion in general. Recently, in the area of the Broad Fourteens Basin (offshore Netherlands, NW of the West Netherlands Basin), De Lugt et al. (2003) addressed the issue of characterization and quantification of the Late Eocene inversion phase. They pointed out that this phase affected a much wider area than the Late 


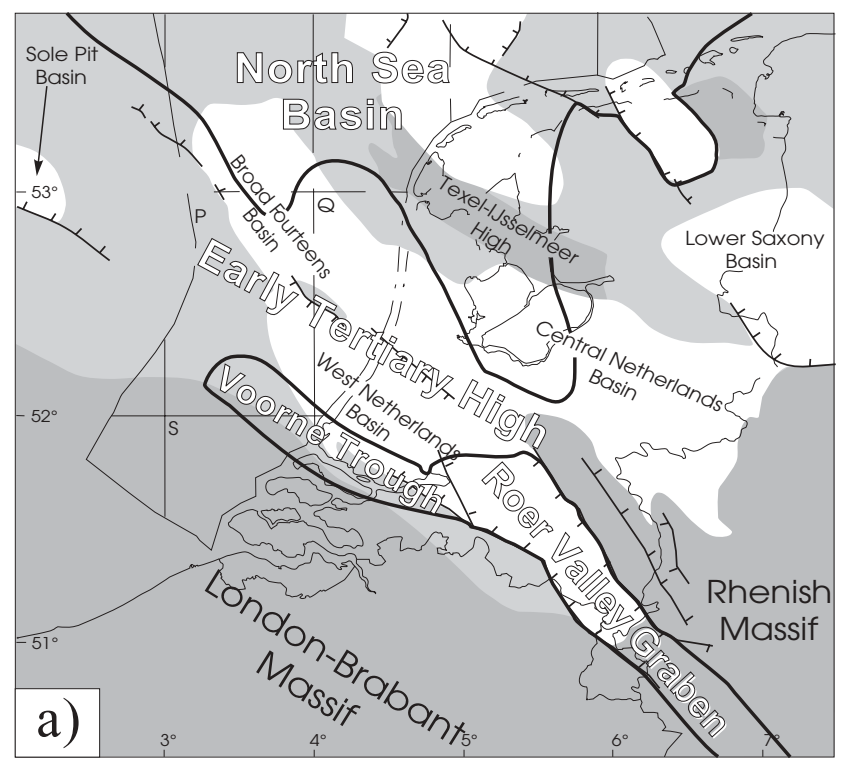

WNB Mesozoic tectonic features

$\perp$ - Main Mesozoic faults

Stable platforms and tectonic

highs during the Mesozoic

Mesozoic sedimentary basins

Tertiary tectonic features

Tertiary depocentres

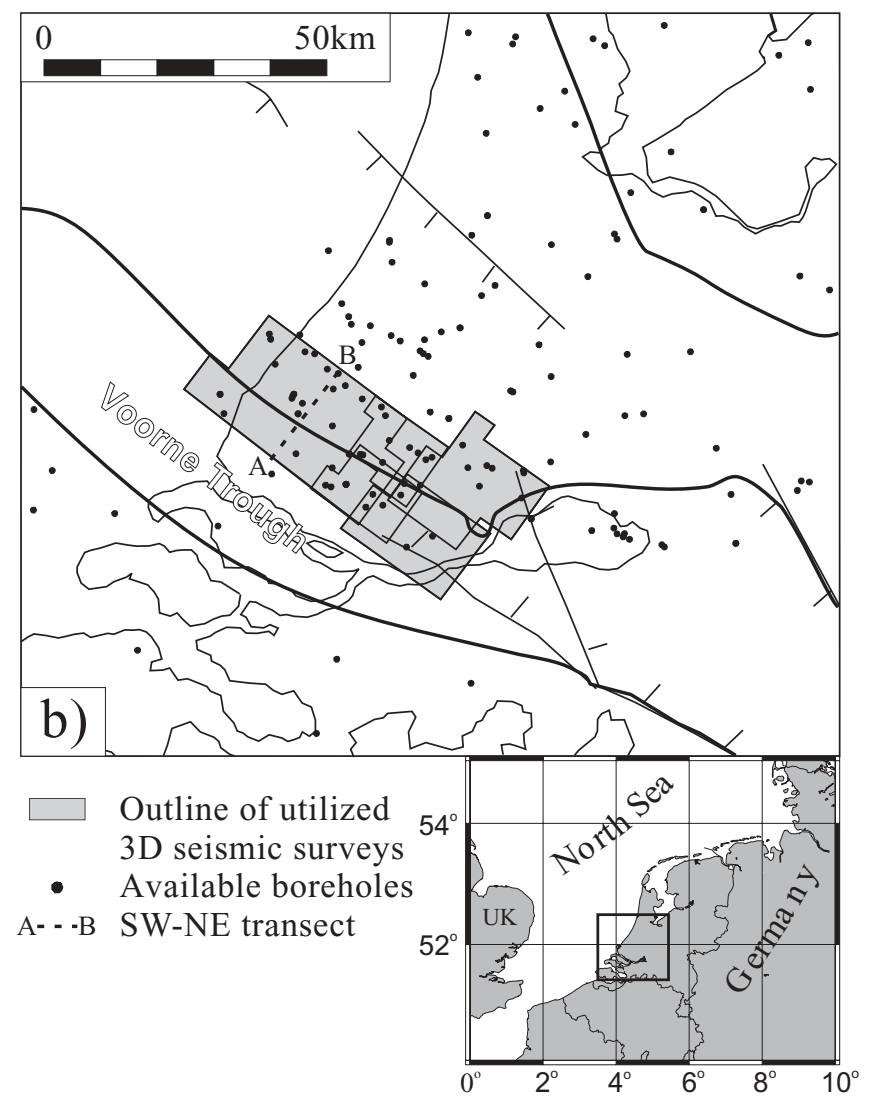

Fig. 1. (a) Main Mesozoic and Tertiary tectonic features of the Netherlands and its surroundings (after TNO-NITG 2002). (b) Three-dimensional seismic surveys and location of wells used in this study. The position of the SW-NE transect A-B (Fig. 3) is indicated.

Cretaceous inversion. They explained this with differently oriented compressive stress fields during the Late Cretaceous and the Eocene. The corresponding uplift was quantified to be $c$. $200-250 \mathrm{~m}$.

Recently, good-quality 3D seismic data became available in the area of the West Netherlands Basin and the Voorne Trough, which provide high-resolution insight into the lower Tertiary sediment structure. In this paper we use this dataset, together with available borehole data, to investigate the various tectonosedimentological aspects of the Late Palaeocene-Eocene geological history of the Early Tertiary High and adjacent Voorne Trough. The aim is to quantify the Late Eocene inversion phase in terms of removed sediment thickness as well as to determine the temporal and spatial characteristics of the Eocene tectonic movements. The characteristics of the determined Palaeogene tectonic evolution are compared with those of the Broad Fourteens Basin and other basins in SE England and in Belgium. Differences observed between the Late Cretaceous-Mid Palaeocene and the Late Eocene inversion phases are also discussed, taking into account the direction of Alpine intraplate compression, the evolution of the Alps and the North Atlantic ridge push.

\section{Data and methods}

\section{Stratigraphy}

The Palaeogene stratigraphy in the study area shows a cyclic sequence of marine clays alternating with marginal marine-to-lagoonal sands and clays on top of the mid-Palaeocene erosional surface (e.g. Letsch \& Sissingh 1983; Zagwijn 1989). In this study we adopt the litho- chronostratigraphic chart presented by Van Adrichem Boogaert \& Kouwe (1997) (Fig. 2). The sedimentary succession starts with a thin basal sandy unit, the Heers Member of the Landen Formation, followed by the Landen Clay Member, representing the climax of the first marine transgression. The Landen Formation is followed by the Dongen Formation, which is subdivided into four members: the thin basal Dongen Sand Member, the Ieper Member, the Brussel Sand Member and the Asse Member. The Ieper and Asse Members represent major transgressional periods, which are also observed elsewhere in the southern North Sea region (e.g. Curry 1992; Vandenberghe et al. 1998). In the centre of the former West Netherlands Basin these members are not present, probably as a result of the subsequent Late Eocene inversion phase, but they are preserved in the Voorne Trough.

The Oligocene succession preserved in the area is represented by the Rupel Formation, whose deposition coincides with another major transgression. The succeeding Late Oligocene Veldhoven Formation is missing in the study area, but it is preserved elsewhere in the southern Netherlands. The regional unconformity separating the Rupel Formation and the overlying Breda Formation of Miocene age is partly the result of a major sea-level drop in the Late Oligocene. Besides the sea-level drop, however, a gentle tectonic uplift representing the latest inversion phase is also suggested to play a role in this erosion (e.g. Ziegler 1987).

\section{Seismic data and mapping}

This study is to a great extent based on public onshore 3D seismic data (Fig. 1b) provided by the National Geological Survey (TNO-NITG). For a detailed investigation of the various Eocene sedimentary units, five easily detectable regional reflectors were mapped and converted into $2 \mathrm{D}$ grids. The time grids were depth-converted using a linear velocity model with parameters representing the velocity-depth trend of the Cenozoic North Sea Supergroup (TNO-NITG 2002). This velocity model was 


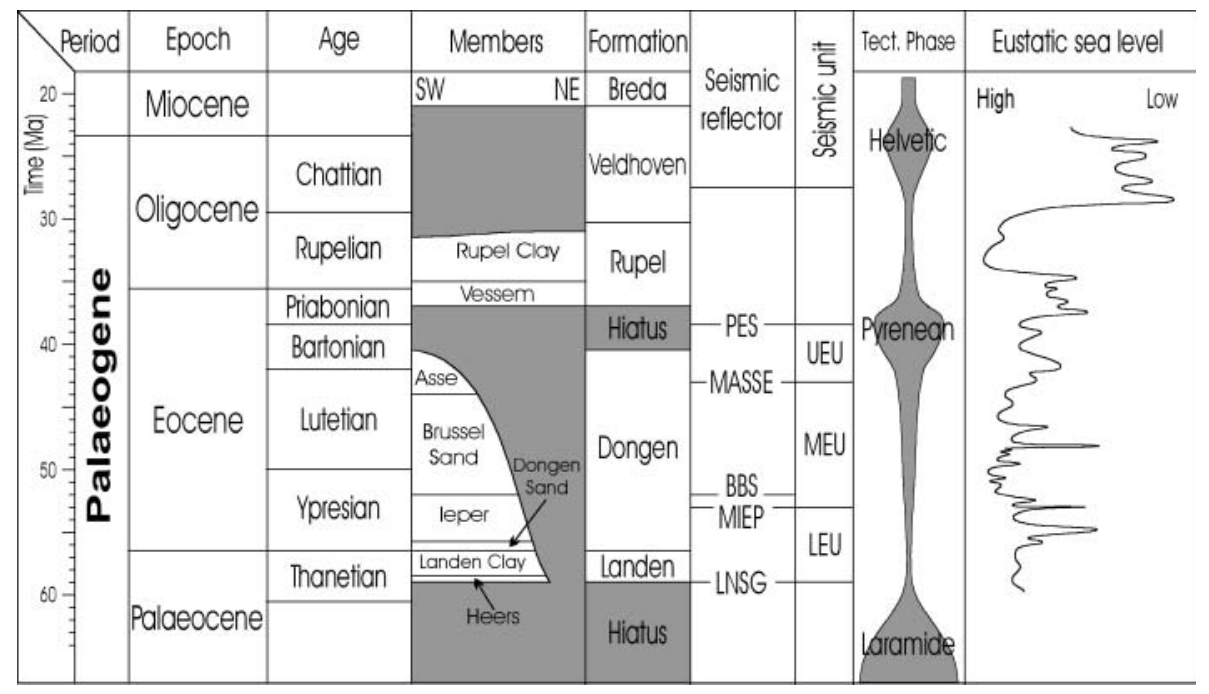

Fig. 2. Palaeogene litho-chronostratigraphic chart for the West Netherlands Basin area, modified after Van Adrichem Boogaert \& Kouwe (1997). Seismic reflectors and seismic units analysed in this study are also indicated. LEU, MEU and UEU, Lower, Middle and Upper Eocene Unit, respectively. TWT, two-way travel time. found to be valid also for other horizons within the clastic Cenozoic succession (see also De Lugt et al. 2003).

The seismic reflectors marked LNSG and PES represent respectively the base of the Lower North Sea Group horizon and the Late Eocene Pyrenean erosional surface (Figs 2 and 3). In the case of the LNSG horizon there is a $5 \%$ mismatch between depth values obtained from wells and from the depth-converted grid. Regarding the PES the discrepancy is higher and is very high in some wells. The reason for this is that in these wells the log-based lithostratigraphic subdivision of the Oligocene-Miocene interval is often uncertain and other stratigraphic markers, which could help the precise subdivision, are not available (Doornenbal, pers. comm.). To resolve this uncertainty, biostratigraphic dating of cuttings from three wells was carried out, which confirmed that the PES reflector represents the base of the Oligocene (Munsterman, unpubl. data).

For a precise geometric reconstruction of the eroded material (discussed below) the Eocene succession has to be subdivided into as many as possible, but not too thin, sedimentary packages. In contrast to the work of De Lugt et al. (2003), it was found that some of the lithostratigraphic boundaries are not represented on the seismic sections by a continuous, well-detectable reflector. In addition, subdivision of the seismic sequence based on lithostratigraphy would result in an alternating series of too thick and too thin sedimentary units, which are not ideal for the thickness reconstruction. For this reason, two easily mappable reflectors were selected (reflectors in the middle-upper part of the Ieper Member (MIEP) and in the lower-middle part of the Asse Member (MASSE)), which divide the Eocene sequence into three units of approximately equal thickness.

The fifth mapped reflector (reflector BBS: Base Brussel Sand Member), is not used in the estimation of the amount of erosion. The purpose of the mapping of this reflector was to check the quality of the depth conversion by comparing the depth-converted grid with well data. The comparison confirmed that the parameters used for the depth conversion provide adequately matching depth maps.

\section{Well data}

Besides the seismic surveys, a large number of public borehole data are also available. For the investigated stratigraphic interval (Late Palaeocene-Eocene), in many of the boreholes lithostratigraphic subdivision of the penetrated strata as well as gamma-ray, sonic and density logs are available.

We use the available sonic and density logs to estimate the amount of sediments eroded during the Late Eocene inversion phase. The principle of the method is the observation that the porosity as well as other, porosity-related, measurable physical properties (interval velocity, bulk density) of a given lithological unit follow a clearly depth-controlled path, provided that no perturbing effects (uplift, erosion, overpressure, etc.) occur during and after the burial. As compaction is an irreversible process, sonic velocities higher than that expected from the normal trend (i.e. positive burial anomaly) may indicate erosion, which is estimated by the sum of the measured burial anomaly and the thickness of the posterosion sediments (e.g. Hillis 1993; Japsen 1998, 2000). It should be noted that the method does not work if the post-erosion sediment thickness overcomes the amount of erosion, as in this case the burial anomaly is destroyed.

\section{Results}

\section{Spatio-temporal reconstruction of the Eocene tectonic movements}

Correlation of the seismic and well data reveals that the Early Palaeogene clastic sediments unconformably overlie the MidPalaeocene erosional surface (LNSG; Fig. 3). This horizon truncates the underlying reflectors, as a result of the Late Cretaceous and Mid-Palaeocene inversion phases. It is important to note that onlap onto this basal surface is not observed (see also De Lugt et al. 2003). This implies that (1) the erosion following the Late Cretaceous-Mid-Palaeocene inversion phases levelled out any relief generated by the inversion, resulting in a flat morphology at the onset of the clastic sedimentation, and (2) the Late Palaeocene marine transgression was relatively fast.

The Eocene sediments overlying the LNSG reflector are characterized by SW-dipping subparallel reflectors truncated by a horizon representing the Late Eocene tectonic phase (PES). A closer inspection of these reflectors reveals that the Eocene units thin towards the NE (axis of the Early Tertiary High). Considering that no onlap is observed onto the LNSG horizon, this thinning indicates differential subsidence between the Voorne Trough and the Early Tertiary High during the Eocene. This differential subsidence suggests differential compaction and/or the dome-like, synsedimentary uplift of the Early Tertiary High relative to the Voorne Trough during the Eocene.

For a more detailed analysis two thickness maps were created from the depth-converted horizons. They represent the sedimentary units between the LNSG and MIEP horizons and the MIEP and MASSE horizons. For the sake of simplicity we refer to these sedimentary units as the Lower Eocene Unit and Middle Eocene Unit, respectively. It is worth noting that these maps represent complete sedimentary sequences not affected by later 

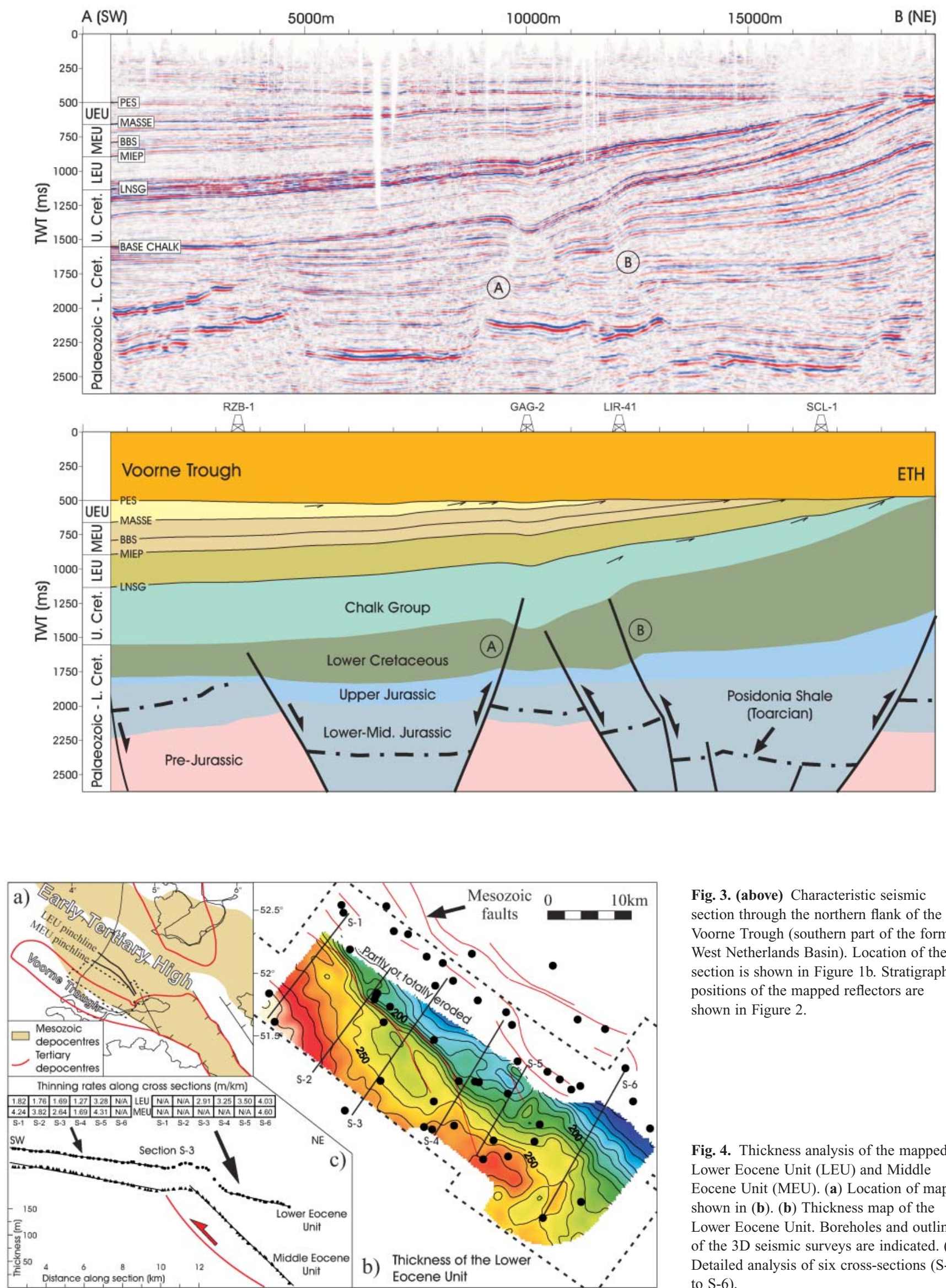

Fig. 3. (above) Characteristic seismic section through the northern flank of the Voorne Trough (southern part of the former West Netherlands Basin). Location of the section is shown in Figure 1b. Stratigraphic positions of the mapped reflectors are shown in Figure 2.

Fig. 4. Thickness analysis of the mapped Lower Eocene Unit (LEU) and Middle Eocene Unit (MEU). (a) Location of map shown in (b). (b) Thickness map of the Lower Eocene Unit. Boreholes and outline of the 3D seismic surveys are indicated. (c) Detailed analysis of six cross-sections (S-1 to S-6). 
erosion (i.e. Late Eocene Pyrenean phase). In other words, the observed thickness variations are the results of tectonic (differential tectonic subsidence) and sedimentary (compaction effects) processes.

As the patterns of the two thickness maps are similar, only the Lower Eocene Unit is presented (Fig. 4b). The map shows a definite thinning of the Lower Eocene Unit towards the NE. As mentioned above, this can be attributed either to the doming of the inverted West Netherlands Basin relative to the Voorne Trough during the Eocene as a result of tectonic forces, or to differential compaction between the northeastern and the central part of the Voorne Trough. This latter possibility can be a reasonable explanation of the thinning, because, as shown in Figure 3, the amount of uplift and erosion resulting from the Late Cretaceous-Mid-Palaeocene inversion phases increases towards the NE. Consequently, at the onset of the Late Palaeocene sedimentation the Mesozoic basement was overcompacted in the West Netherlands Basin, where significant erosion occurred, and was normally compacted in the Voorne Trough, which was not affected by erosion. The Late Palaeocene-Eocene sedimentary load caused further compaction of the Mesozoic basement, resulting in extra accommodation space, whereas this did not happen in the internal parts of the West Netherlands Basin until the Mesozoic rocks reached their pre-inversion maximum depth of burial. One-dimensional backstripping analysis of four wells (discussed in detail below) suggests that although differential compaction played an important role in the observed thinning, the existence of tectonically driven differential uplift cannot be excluded.

In the following section evidence is presented that implies that synsedimentary tectonic movements took place during the Eocene. The first feature implying this is the abrupt thickness change across old Mesozoic faults (fault B in Fig. 3), which indicates fault reactivation during deposition (Fig. 4). The fault orientation implies reverse faulting, which is in agreement with the compressional tectonic setting proposed for the Eocene (e.g. De Lugt et al. 2003; Michon et al. 2003). A more detailed analysis of the thickness maps was carried out on six crosssections (Fig. 4b and c). These cross-sections reveal that the rate of thinning is higher on the hanging-wall side of the fault than on the footwall side. This suggests syndeposition deformation of the hanging-wall block and consequently synsedimentary reverse faulting during the Eocene.

Figure $4 \mathrm{c}$ shows that the thinning towards the NE can be represented by one or two linear trends (Fig. 4c), which are generally separated by a fault. Using regression analysis for every cross-section and for both the Lower Eocene and the Middle Eocene thickness maps, the thinning rates and the location of the pinchline (where the thickness reduces to zero) can be determined (Fig. 4b and c). The pinchline geometrically estimates the northern depositional boundary of the given unit. These parameters show that the thinning rate of the Middle Eocene Unit is always higher than that of the Lower Eocene Unit and that the pinchline of the Middle Eocene Unit is closer to the centre of the Voorne Trough than is that of the Lower Eocene Unit. These observations suggest that during the Eocene (1) the northern boundary of the sedimentation moved towards the SW and (2) the Voorne Trough became narrower and its northeastern flank became steeper. In addition, as the pinchlines are located on the southern flank of the Early Tertiary High and not in its centre or on its northern side, we conclude that the Early Tertiary High was probably a tectonic high during the Eocene, on which much less sediment was deposited than previously thought.

The lack of onlap onto the LNSG surface suggests that at the onset of the Late Palaeocene clastic sedimentation the area was relatively flat with no significant topography. At present, the LNSG horizon dips significantly towards the SW as a result of the Eocene and later tectonic movements. Assuming that the top of the sedimentary column was always horizontal during the Eocene, the shape of the LNSG horizon at any given time can be restored. Analysis of the dip of the restored LNSG horizon and the rate of dip change between two subsequent stages provide valuable information on the spatial and temporal characteristics of the deformation (doming) during the Eocene.

For the restoration of the LNSG horizon we use three stages represented by the MIEP, MASSE and PES horizons. The restoration was achieved by subtracting the corresponding depth grid from the grid representing the present-day LNSG horizon (i.e. horizon flattening). Then the state of dip of the restored LNSG horizon was determined by calculating its first-order directional derivative $\left(\mathrm{N} 45^{\circ}\right)$. Finally, three dip-rate maps were calculated by dividing at every point in the grid the dip difference between two subsequent stages by the time difference.

The age of the lowermost Heers Member (59 Ma) was used as the age of the LNSG reflector, whereas the PES horizon was suggested to represent the middle of the Late Eocene-Oligocene hiatus (c. base Priabonian $38 \mathrm{Ma}$; Van Adrichem Boogaert \& Kouwe 1997). As the MIEP and MASSE horizons do not represent particular stratigraphic boundaries, their ages were determined by linear interpolation between known age markers in the boreholes. As age markers the base Ieper Member, the base Brussel Sand Member and the base Asse Member were used. The final ages of the horizons (MIEP $53 \pm 0.27 \mathrm{Ma}$, MASSE $43 \pm 1 \mathrm{Ma}$ ) were determined by averaging the ages obtained from different wells.

Figure 5 shows the rate of tilting of the LNSG horizon for three subsequent time intervals. Because of the uncertainty of the age determination the actual dip-rates may be slightly different. It should be noted that the tilting represented by Figure 5 is the collective result of tectonics and the compaction of the sediments underlying the given unit. However, as mechanical compaction is time independent and as the thickness of the three mapped Eocene units is approximately equal, it is suggested that the effect of compaction of the underlying sediments in all three cases can be represented by a uniform or similar pattern. Consequently, although the real rate of tectonic tilting is not known these patterns are suitable to qualitatively compare the tectonic activity between subsequent stages: faster rate of tilting reflects stronger tectonic activity.

During the deposition of the Lower Eocene Unit (Fig. 5a), besides fault activity, a strong differential tilting can be observed between the eastern and western part of the map, which is attributed to tectonic activity. During the Mid-Eocene (Fig. 5b) the tilting became smoother and more uniform compared with the Early Eocene. In addition, its average magnitude also decreased slightly. Taking into account the larger compaction of the Lower Eocene Unit compared with the Middle Eocene Unit (sandy clay v. sand) the difference in tilting rate between these two units is probably even larger. This may imply that tectonic activity during the deposition of the Middle Eocene Unit was reduced. In the third time interval, tilting rates $2-3$ times higher than in the previous periods can be observed, which can be attributed to the Late Eocene inversion phase (Fig. 5c). This inversion period led to the reactivation of several, previously inactive Mesozoic faults, clearly suggesting that the tectonic movements in the Late Eocene were stronger than those during the Early-Mid-Eocene period.

The present analysis provides new constraints on the Eocene 


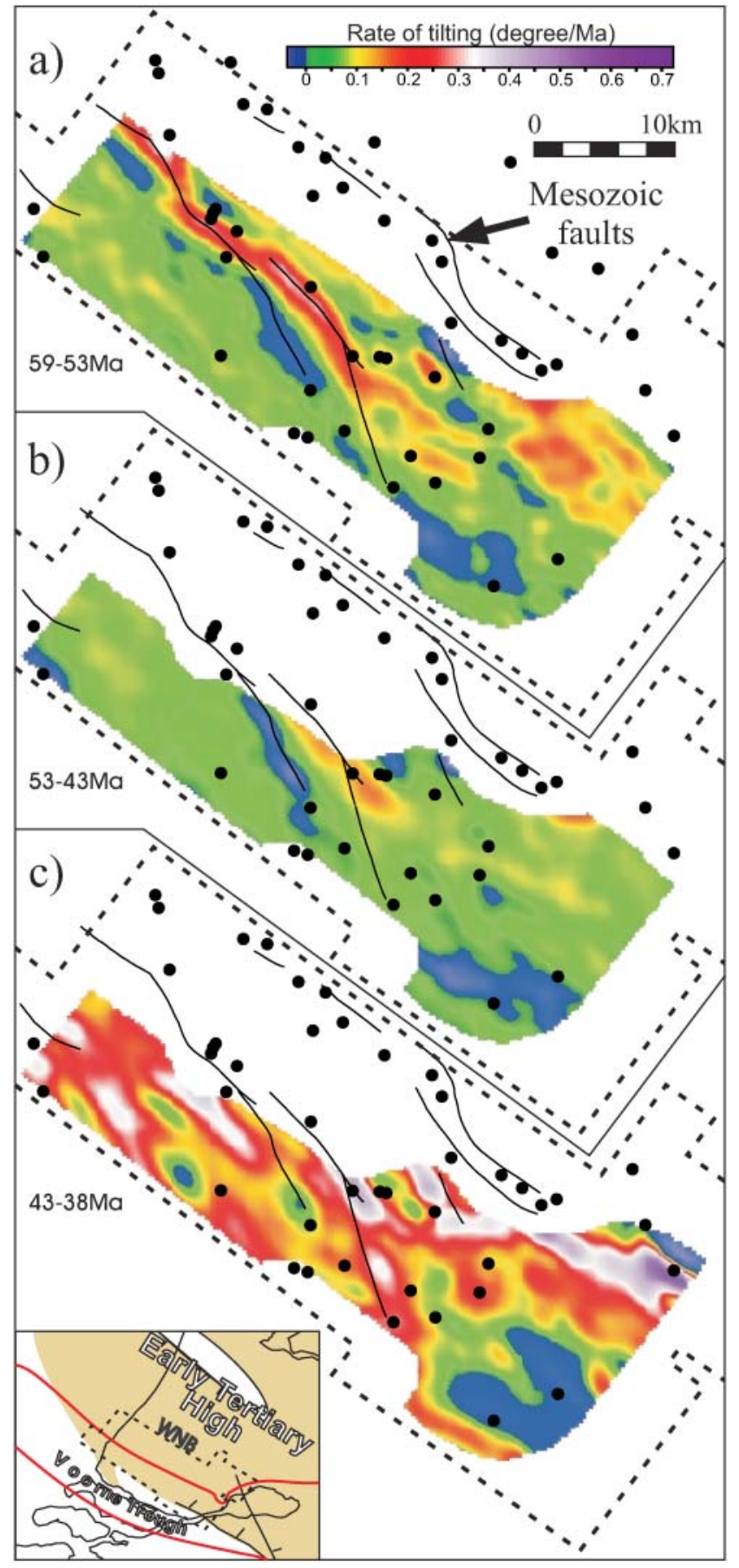

Fig. 5. Reconstructed rate of tilting of the base Lower North Sea Group reflector (LNSG) for three Eocene time intervals. (a) Lower Eocene Unit (59-53 Ma); (b) Middle Eocene Unit (53-43 Ma); (c) Upper Eocene Unit (43-38 Ma, Pyrenean invesion phase). Higher values represent faster tilting and consequently stronger tectonic movements. WNB, West Netherlands Basin. Boreholes and outline of the 3D seismic surveys are indicated. (See text for further discussion.)

evolution of the West Netherlands Basin. To sum up, we conclude that the present-day tilted and faulted states of the Eocene sediments are the collective result of differential compaction and a cumulative, continuous deformation throughout the
Eocene rather than a single tectonic pulse. The Late Eocene Pyrenean inversion phase was much stronger than the EarlyMid-Eocene tectonic movements and is interpreted as a climax of the compressional intraplate stresses at the end of the Eocene. As the seismic data demonstrate, the Eocene deformation, which is characterized by the continuous doming of the Early Tertiary High relative to the Voorne Trough, was accompanied by reverse reactivation of major Mesozoic faults. The doming at the end of the Eocene was complemented by the reactivation of additional faults and is characterized by a c. $50 \mathrm{~km}$ wavelength (i.e. the width of the Early Tertiary High).

\section{Quantitative reconstruction of the amount of erosion}

Burial anomaly analysis. For the burial anomaly analysis, which was performed in 37 wells using sonic and density logs, it is essential to choose a stratigraphic interval for which lithology does not change significantly within the interval and over large distances. Thus apparent anomalies can be avoided. For this reason, we selected the upper part of the Landen Clay Member, of Late Palaeocene age (Fig. 6). The Landen Clay is a silty or sandy clay layer, which shows an upward-increasing gamma-ray and an upward-decreasing sonic velocity response. In the upper part of the layer selected for the analysis the gamma-ray and sonic $\log$ responses do not change significantly (or are stationary) and reach respectively their local maximum and minimum (Fig. 6). The characteristic log response of the Landen Clay Member was very useful to identify and correlate this interval in wells located far from each other or where detailed lithostratigraphic interpretation was not available.

Interval velocities. Nine of the 37 wells where sonic logs were available are located north of the Early Tertiary High. The rest of the wells are located south of this high, partly in the Voorne Trough (Fig. 6c). The average sonic velocity of the selected interval was calculated using the integrated travel time (ITT) and the thickness of the interval. In cases where the ITT peaks were not displayed along the sonic log manually averaged slowness values were obtained, which later were transformed into interval velocity. The true vertical depth of the midpoint of the interval represents the reference depth for every interval velocity reading. The true vertical depth was calculated using the path of the well.

The resulting velocity-depth pairs are shown in Figure $6 \mathrm{~b}$. Wells BAC-1, IJM-1, MID-101, PRW-1 and ALE-1 are excluded from the analysis, as in these wells the Landen Formation is very thin or the calculated interval velocities resulted in abnormally low values. The figure shows that in wells located north of the Early Tertiary High the interval velocities are lower than in those situated in the Voorne Trough. Such a characteristic suggests lithological and/or textural differences within the Landen Clay Member between the two areas (i.e. less sand north of the Early Tertiary High). The possible lithological differences can be related to the nearshore position of Voorne Trough and the more distal position of the area north of the Early Tertiary High (e.g. Letsch \& Sissingh 1983). An alternative explanation of the lithological differences can be given by assuming sedimentation in two detached sub-basins separated by a sediment barrier, namely the Early Tertiary High.

To determine the normal depth trend, a linear regression line was fitted to specific data points, which correspond to wells where no erosion is expected (i.e. deeper parts of the Voorne Trough), and where the quality of the log response is best. The majority of the wells, including those on the strongly truncated northern flank of the Voorne Trough, show interval velocities in agreement with the depth trend. This suggests that in these wells 


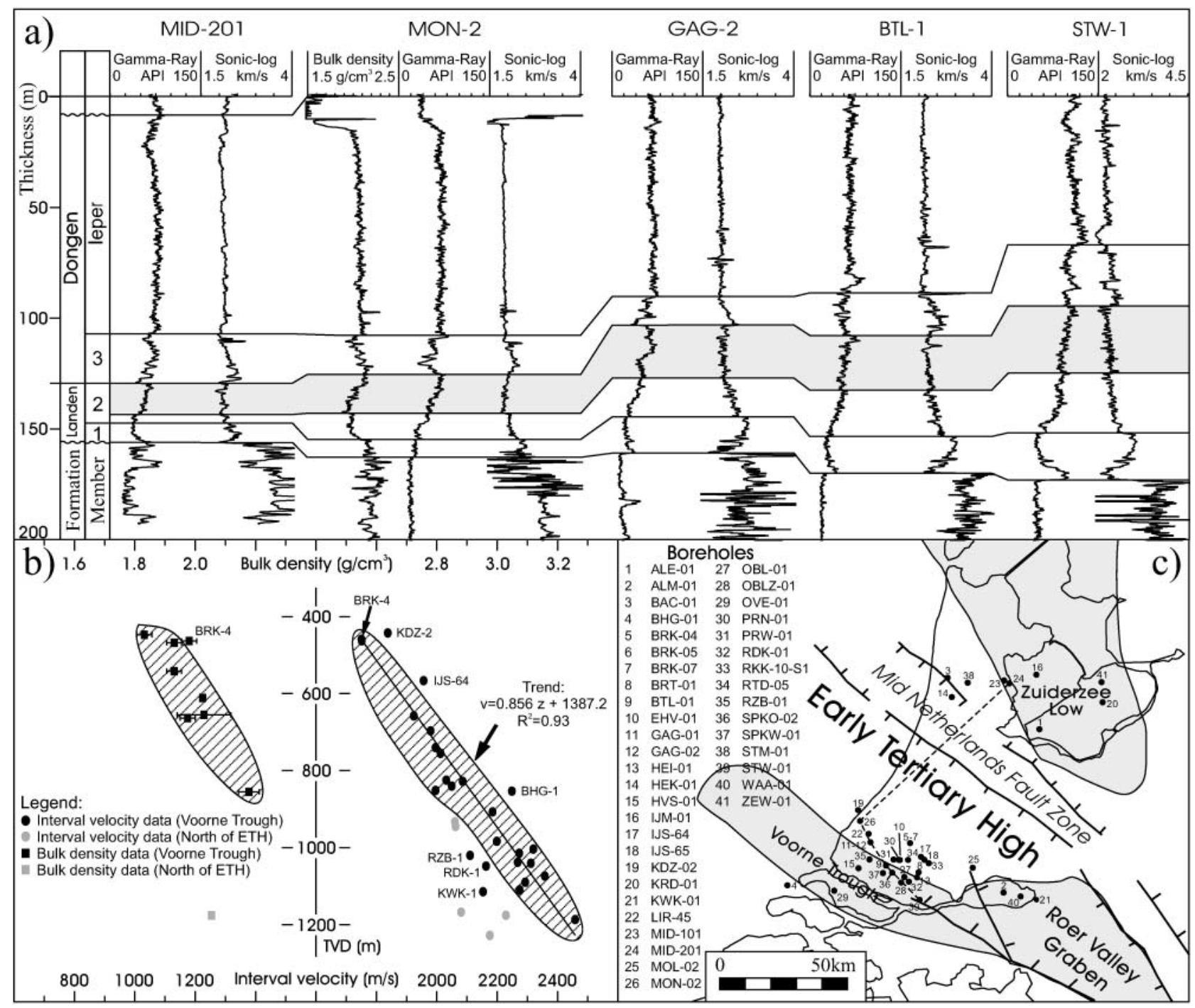

Fig. 6. Burial anomaly analysis. (a) Characteristic sonic, gamma-ray and density log responses of the Landen and the lower part of the Dongen Formation in five representative wells located in the Voorne Trough and Zuiderzee Low; location shown in (c). The investigated stratigraphic interval is shown in grey. 1, Heers Member; 2, Landen Clay Member; 3, Basal Dongen Sand Member. (b) Interval velocity and bulk density of the 'grey layer' in different wells. Vertical axis represents true vertical depth (TVD). ETH, Early Tertiary High. (c) List and location of the boreholes used in the analysis. The dashed line indicates the cross-section shown in (a). (See text for discussion.)

the Late Eocene erosion is masked by the post-inversion sedimentation. In consequence, this observation indicates that the erosion does not exceed the thickness of the post-inversion sediments (c. 450-550 m).

Wells KDZ-2, IJS-64 and BHG-1 show positive burial anomalies relative to the trend, but none of them is concluded to be a true burial anomaly related to uplift. Well BHG-1 is located on the southernmost flank of the Voorne Trough, close to the fringe of the basin. Therefore, the investigated interval in this well has probably a sandier lithology, which could explain the $100 \mathrm{~m} \mathrm{~s}^{-1}$ higher sonic velocity. For wells KDZ-2 and IJS-64 the observed $120 \mathrm{~m}$ burial anomaly (considering respectively the $500 \mathrm{~m}$ and $589 \mathrm{~m}$ of post-Pyrenean sedimentation) would yield $620 \mathrm{~m}$ and $709 \mathrm{~m}$ of erosion. This is unlikely, as interval velocities of wells in similar tectonic position are in agreement with the depth trend. For KDZ-2 it is more probable that the observed higher sonic velocity is also the result of lithological differences, as in this well, because of the Late Eocene truncation, only the sandier lower part of the Landen Clay is preserved and could be measured.

In wells RZB-1, RDK-1 and KWK-1 significant negative anomalies were found. Taking into account their location in the Voorne Trough and values from surrounding wells, there is no clear explanation for these anomalies.

Bulk densities. Density logs were available for 10 wells. All the wells except KRD-1 are located south of the Early Tertiary High. As the logs were available only on paper prints the average bulk density within the interval was obtained by manual averaging.

The bulk density-depth pairs are in agreement with the interval velocity analysis (Fig. 6b). They follow a quasi-linear trend and only three minor fluctuations (two positive (BRK-4 and BRK-7) and one negative (MOL-2)) are observed. Lithological or borehole conditions could not explain these fluctuations. Considering the position of the wells, however, it is unlikely that they are caused by erosion. Well KRD-1, which is located north 
of the Early Tertiary High, is represented by a lower bulk density value than that expected from the trend south of the Early Tertiary High. We also observed this difference between the two flanks of the Early Tertiary High in the interval velocities.

The analysis of sonic and density logs demonstrated that both the interval velocity and the bulk density of the investigated lithological unit (upper part of the Landen Clay Member) show linear trends with depth. In the area covered by the selected wells (i.e. on the northern and southern rims of the Early Tertiary High) the upper Palaeocene Landen Formation at present is at maximum depth of burial. Consequently, it can be deduced that on the rims of the Early Tertiary High the thickness of the eroded Palaeogene sediments is less than the $450-550 \mathrm{~m}$ thickness of the post-inversion sediments.

Geometric approach. As the analysis of the sonic and density data provides only a maximum value for the erosion (i.e. 450$550 \mathrm{~m}$ ) we adopt a complementary approach (i.e. a geometric approach) to better constrain the amount of erosion during the Late Eocene. The basic assumption of the method is that the amount of deposited and later eroded Eocene material is equal to the difference between the present-day base Oligocene horizon (PES) and a fictional one, which could be observed if erosion had not occurred (Fig. 7). This fictional (or restored) base Oligocene horizon is calculated by adding the restored thickness of the Eocene sediments to the LNSG horizon. To estimate the thickness of the deposited Lower and Middle Eocene Units we linearly extrapolate their observed thickness using thinning rates and pinchlines obtained during the analysis of the thickness maps. In locations where they are preserved we use, of course, the observed values. To estimate the uppermost Eocene, erosionaffected unit (c. Asse Member), we use a wedge-shaped body. Its maximum thickness corresponds to the maximum thickness of this unit observed in wells located in the centre of the Voorne Trough, whereas its pinchline coincides with the pinchline determined for the Middle Eocene Unit. It should be noted that because of this approach the estimated erosion is relative and is zero in the central part of the Voorne Trough. To determine the absolute erosion, one should estimate the thickness of the nowhere preserved uppermost Eocene sediments. Also, it should be noted that the erosion determined in this way estimates only the amount of deposited and later removed Eocene sediments. The amount of Mesozoic sediments, which were removed from locations where none of the Palaeogene sediments are preserved (e.g. central part of the Early Tertiary High), are not and cannot be taken into account with this method.

The map of removed Eocene sediments shows increasing erosion towards the NE (Fig. 7b). The amount of erosion reaches its maximum (c. $250 \mathrm{~m}$ ) in a NW-SE-trending zone above popup structures related to reactivated Mesozoic faults. In the axis of this zone the Late Palaeocene-Eocene sediments are completely removed, therefore the true erosion is underestimated.

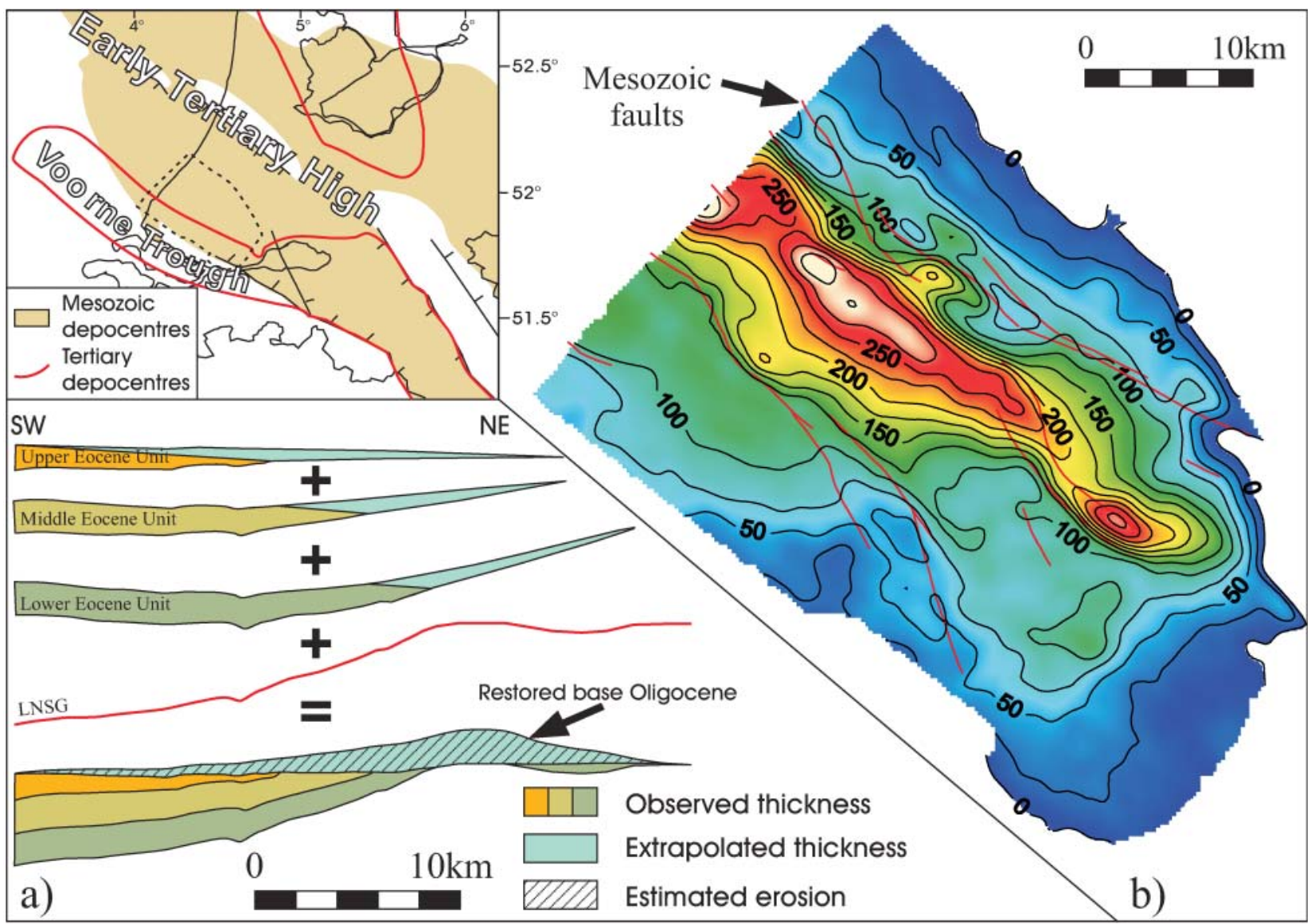

Fig. 7. Geometric reconstruction of the amount of Upper Palaeocene-Eocene sediments removed by the Late Eocene Pyrenean inversion phase. (a) Principles of the reconstruction. (b) Map of estimated erosion. Outline of the map is indicated in the inset. It should be noted that the estimated erosion is relative: the reference point is located in the centre of the Voorne Trough. (See text for further discussion.) 
Because the thickness of the deposited Eocene sediments was extrapolated, the amount of determined erosion becomes less reliable towards the NE.

The above results are not in disagreement with the results of the burial anomaly analysis. Compiling the results of the two approaches we estimate that the Late Eocene Pyrenean inversion phase removed c. 250-450 m of Eocene sediments from a NWSE-trending zone in the southern part of the West Netherlands Basin. Towards the NE, in the central part of the basin, the amount of deposited sediments that were later removed by the Late Eocene inversion cannot be reliably estimated because of the lack of preserved Eocene layers. In this part of the study area, where Mesozoic rocks are overlain by Oligocene and younger sediments, one should use interval velocity data of Mesozoic sediments to estimate the erosion. In that case, however, it would be impossible to separate the effects of the Late Cretaceous, Mid-Palaeocene and Late Eocene inversion phases.

\section{Discussion}

\section{Differential subsidence $v$. compaction}

As mentioned above, the observed NE thinning of the Eocene sediments in the Voorne Trough, besides tectonic doming, could also be explained by differently compacted Mesozoic basement resulting from the Late Cretaceous-Mid-Palaeocene erosion. The backstripping method (e.g. Sclater \& Christie 1980) separates isostatic and compaction effects of sediments from those of tectonic subsidence. The aim of the analysis presented in this section is to qualitatively compare the tectonic subsidence between the Voorne Trough and the Early Tertiary High during the Eocene. The input stratigraphic time-depth information and the amount of erosion for the four analysed wells are shown in Figure 8 . The amount of erosion was constrained by the results of the present paper and by unpublished interval velocity data for the Lower Cretaceous sediments. The porosity-depth relations were calculated with Genex software, using world-average porosity-depth relations for lithologically pure formations and the lithological composition of the various sedimentary units ('mixing rule'). Erosion and subsequent overcompaction were taken into account in the calculation. Sea-level changes and water depth were neglected, as they have the same effect on all four wells.

Comparison of the tectonic subsidence curves for the Voorne Trough and the Early Tertiary High reveals that using the simple assumption of mechanical compaction and Airy isostasy the Eocene sedimentation can be explained without the presence of differential tectonics. In fact, tectonic subsidence was calculated to be slightly higher in the Early Tertiary High than in the Voorne Trough. This would be in total disagreement with the observations presented in this paper. It should be noted, however, that several important factors are not taken into account in the calculation. For example, a 1D Airy isostatic model was used instead of the more satisfactory 2D flexural isostatic approach. In reality, the load of the thick Eocene sediments in the Voorne Trough also contributed to the subsidence of the Early Tertiary High, which, if taken into account, would result in smaller calculated tectonic subsidence in the Early Tertiary High. It is reasonable to assume also some amount of erosion and consequently overcompaction of the Mesozoic sediments in the Voorne Trough prior to the Eocene sedimentation, which would result in higher tectonic subsidence in the Voorne Trough. The most important factor affecting the calculated tectonic subsidence is the compaction of the Chalk Group, as this is the thickest preEocene sedimentary unit in the Voorne Trough. It has been pointed out in diagenetic studies of chalks that although mechanical compaction to a porosity of $40 \%$ can occur (Jones et al. 1984), limy chalk sediments tend to compact mechanically only to $c .250 \mathrm{~m}$ depth and only slightly or not at all below that (e.g. Pettijohn 1984; Grützner \& Mienert 1999; Mallon \& Swarbrick

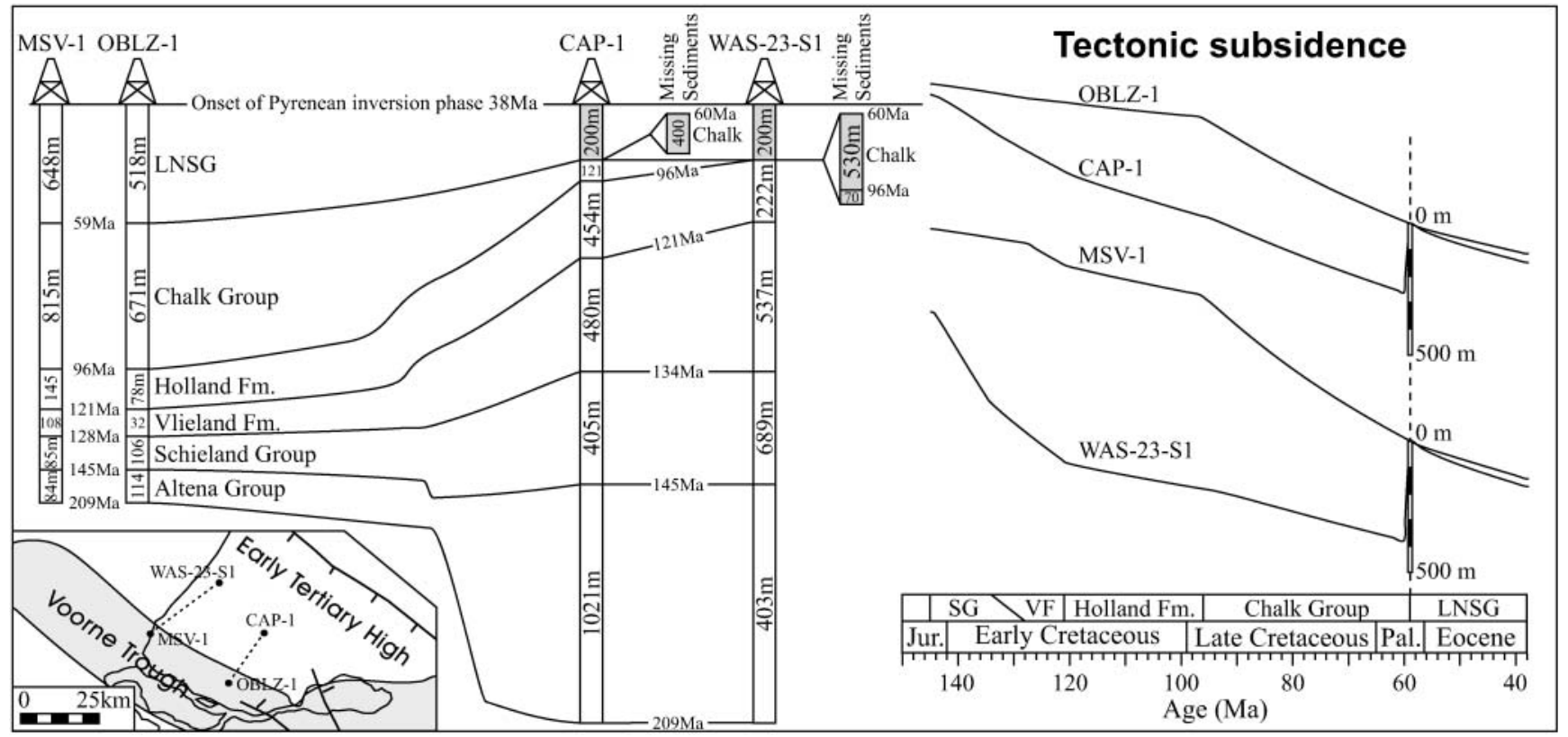

Fig. 8. Jurassic-Eocene tectonic subsidence of four synthetic wells located in the West Netherlands Basin. The thickness of the grey-shaded sedimentary units (those removed by erosion) is an estimate; the others are taken from real wells. The thickness bars are not scaled. The origins of the curves were set to the base of the LNSG unit. Overcompaction of the Mesozoic sediments in wells CAP-1 and WAS-23-S1 as a result of the Mid-Palaeocene uplift and erosion is taken into account. LNSG, Lower North Sea Group; SG, Schieland Group; VF, Vlieland Formation. (See text for discussion.) 
2002; Fabricius 2003). Pore-filling cementation is also common during the diagenesis of chalks, resulting in rapid porosity loss. In other words, the observed porosity loss in chalks (e.g. Mallon \& Swarbrick 2002) is rather the result of chemical processes than of grain reorganization and consequently bulk volume loss.

Taking into account the above-mentioned factors would probably result in larger calculated tectonic subsidence in the Voorne Trough than in the Early Tertiary High during the Eocene, which would be in accordance with the synsedimentary features presented in this paper. However, quantitative demonstration cannot be provided here, as the software available to us cannot handle such complex models. To sum up, we conclude that, although compaction of the pre-Eocene sediments must have significantly contributed to the thinning and tilted state of the Eocene sediments, differential tectonic movements between the Voorne Trough and the Early Tertiary High also operated during the Eocene.

\section{Characteristics and timing of inversion}

Southern North Sea region. Our study allows quantification of the uplift of the West Netherlands Basin related to the Late Eocene inversion phase. At a regional scale, a similar deformation was recognized for the Broad Fourteens Basin (Nalpas et al. 1995; De Lugt et al. 2003), the Roer Valley Graben (e.g. Michon et al. 2003) and the Sole Pit Basin (e.g. Van Hoorn 1987) (Fig. 1). The average amount of uplift is of the same order of magnitude in these four provinces (i.e. $200-400 \mathrm{~m}$ in the Sole Pit Basin (Cameron et al. 1992), 200-500 $\mathrm{m}$ in the Broad Fourteens Basin, 250-450 m in the West Netherlands Basin and around $300 \mathrm{~m}$ in the Roer Valley Graben). The style of inversion and consequently the amount of uplift and/or erosion primarily depend on: (1) the tectonic stress field; (2) the geometry of the basin and its main faults; (3) the mechanical parameters of the lithosphere and the basin fill; (4) the duration and amount of lithospheric stretching prior to inversion; (5) the elapsed time between basin formation and inversion (e.g. Gillcrist et al. 1987; Chadwick 1993). From this it follows that the compressive intraplate stresses inducing the inversion must not have been very different in the above-mentioned basins during the Late Eocene, as their Mesozoic basin geometry, basin fill and structural evolution are very similar.

Seismic data analysis shows that the Eocene uplift affected both the West Netherlands Basin and its adjacent areas, forming a $50 \mathrm{~km}$ wide NW-SE-trending dome (i.e. the Early Tertiary High). This geometry differs from the deformation pattern that resulted from the Late Cretaceous and MidPalaeocene inversions. Indeed, during these earlier inversion periods deformation was restricted to the Mesozoic graben and controlled by the reactivation of major faults in reverse mode, whereas during the Eocene the affected area was much wider and fault reactivation was mild. A similar characteristic was determined for the neighbouring Broad Fourteens Basin and the Roer Valley Graben (De Lugt et al. 2003; Michon et al. 2003).

The second main difference between the Late CretaceousMid-Palaeocene and Late Eocene inversion phases is the amount of uplift and eroded sediments. As mentioned above, during the Late Eocene inversion a few hundred metres of sediments were removed. During the Late Cretaceous-Mid-Palaeocene inversion periods the amount of erosion was much greater. For the central part of the Broad Fourteens Basin c. 2000-3000 m of erosion was determined (Nalpas et al. 1995), whereas in the Roer Valley Graben the amount of uplift is less constrained although it definitely exceeds $600 \mathrm{~m}$ (Michon et al. 2003, fig. 7a). In the West Netherlands Basin the Late Cretaceous-Mid-Palaeocene uplift is $600-1500 \mathrm{~m}$ (unpublished data).

Our study reveals that the Late Eocene inversion of the West Netherlands Basin was not a sudden pulse at the end of the Eocene but rather a continuous process throughout the Early Palaeogene, which culminated in the latest Eocene. Continuous, synsedimentary inversion in the Alpine foreland during the Cretaceous-Tertiary period is not a unique feature restricted to the West Netherlands Basin. A similar long-lasting, synsedimentary inversion phase has been reported from the Roer Valley Graben (Gras \& Geluk 1999), the Sole Pit Basin (Van Hoorn 1987) and the Norwegian continental shelf (Vågnes et al. 1998).

Inspection of seismic lines in the neighbouring Broad Fourteens Basin reveals similar thinning of the Eocene sediments towards the centre of the former basin (see internal reflectors of Unit 2 in fig. 10 of De Lugt et al. (2003)). In addition, a drastic decrease in subsidence rates before the onset of the Late Eocene Pyrenean inversion was determined. This evolution is comparable with the Palaeogene evolution of the West Netherlands Basin. It is therefore suggested that an inversion characterized by continuous Eocene tectonic movements or uplift followed by a stronger compressional climax probably occurred in other inverted basins in the southern North Sea region.

English Channel area. Two other inversion examples are discussed briefly below. These areas are located in a different tectonic domain compared with the West Netherlands Basin and experienced different timing of inversion (Fig. 9). However, highlighting and comparison of some important aspects of their inversion could contribute to the better understanding of the inversion process in the Alpine foreland.

The first example is the Tertiary deformation of the Mesozoic Weald and Channel basins, SE onshore and offshore England (e.g. Chadwick 1985; Lake \& Karner 1987; Underhill \& Paterson 1998; Blundell 2002). The Palaeogene tectonic and sedimentary scenario for this basin system is very similar to that for the West Netherlands Basin. In both areas the subsiding Palaeogene basins developed on formerly stable tectonic highs and are separated by newly developed tectonic highs inverted from Mesozoic depocentres. The concept of a single, post-Oligocene deformation phase responsible for the inversion (e.g. Wooldridge \& Linton 1955) has now been replaced by one involving a longer, more

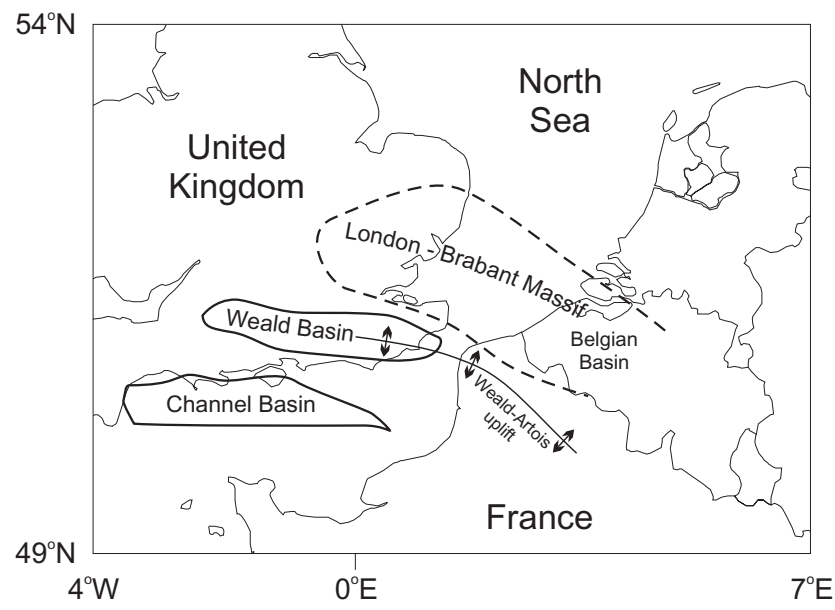

Fig. 9. Location and main tectonic features of the Wessex and Belgian basins. 
complex history of uplift and deformation continuing from the Latest Cretaceous onward (e.g. Jones 1980; Small 1980; Chadwick 1985; Lake \& Karner 1987). Indeed, numerous stratigraphic studies indicate that uplift-related erosion, faulting and warping occurred in SE England from late Early Eocene times onward; that is, preceding the main deformation phase (e.g. Daley \& Edwards 1971; Plint 1982; Isaac \& Plint 1983; Curry 1992; Gale et al. 1999). Although the timing is different, this feature of basin inversion is very similar to the inversion of the West Netherlands Basin.

In the area of the Belgian Basin, which developed during the Palaeogene on the tectonically stable Brabant Massif, the Palaeogene sediments are truncated and eroded in response to eustatic and tectonic causes (e.g. Vandenberghe et al. 1998). The timing of truncation is coeval with the main inversion phase of the Channel area (i.e. Late Oligocene-Miocene) and is related to the uplift of the Weald-Artois axes and the NE tilting of the Brabant Massif. On the other hand, detailed stratigraphic and seismic studies revealed tectonic-related unconformities throughout the Palaeogene succession, suggesting continuous tectonic activity and uplift of the Brabant Massif from the Mid-Eocene onward; that is, preceding the main deformation phase (e.g. Cameron et al. 1992; De Batist \& Henriet 1995; Vandenberghe et al. 1998; De Batist \& Versteeg 1999). Continuous tilting is also indicated by the southward thinning of Eocene seismic layers (e.g. $\mathrm{PA}_{3}$ layer in fig. 9 of De Batist \& Versteeg (1999)). Continuous Palaeogene deformation is comparable with the tectonic history of SE England and of the West Netherlands Basin revealed by our study.

The above examples demonstrate that in the NW European foreland of the Alps the inversion process often continued between two phases. The identified inversion phases therefore are considered as subsequent, multiple culminations of a continuous inversion process. In light of the Euro-African collision being the primary cause of the compressive stresses in the Alpine foreland it is more natural and reasonable to imagine a continuous inversion process rather than one with distinct pulses. However, the exact causes of inversion culmination and the timing of inversion still require explanation.

\section{Origin of the inversion}

It has been proposed for a long time that the Late CretaceousTertiary inversion phases in the southern North Sea region resulted from compressional stresses originating from the Alpine collision (e.g. Ziegler 1990; Blundell 2002). The other source of compressive stress is the ridge-push force originating from the North Atlantic mid-ocean ridge. These two stresses at present constructively interact in NW Europe (e.g. Gölke \& Coblentz 1996).

The Late Cretaceous-Mid-Palaeocene inversions are probably related to Alpine events, as they predate the Early Eocene breakup of the North Atlantic (e.g. Talwani \& Eldholm 1977). Ziegler et al. (1998) envisaged that they are caused by increasing compressional stresses related to the collision of the Alpine orogenic wedge with a subduction pediment (i.e. Briançonnais terrane or microcontinent) after the closure of the PiemontSouth Penninic ocean.

In contrast to the Late Cretaceous events, the Eocene deformation observed in the West Netherlands Basin and other areas in the southern North Sea region is coeval with the North Atlantic sea-floor spreading. However, considering that the magnitude of ridge push is proportional to the age of the produced oceanic lithosphere, it is unlikely that during the Eocene the contribution of the North Atlantic ridge push to the compressional stresses originating from the Alpine region was significant. This assumption is supported by the detailed analysis of Eocene-present-day contractional structures on the Norwegian continental shelf, which suggest that the ridge-push contribution became significant only during the Neogene (Vågnes et al. 1998). In light of these observations it is reasonable to suppose an Alpine origin for the Paleogene deformation in the southern North Sea region.

In the Alps geochronological data for high-pressure metamorphic rocks show that the Eocene period corresponded to a phase of intense deformation with the formation of a deep crustal root (e.g. Monié \& Philippot 1989; Tilton et al. 1991). Consequently, it is paradoxical that a continuous deformation in the Alps during the Eocene resulted in a sudden inversion phase only in the latest Eocene. In the light of our results, it clearly appears that the continuous compression in the Alpine chain led to a continuous inversion in the southern North Sea during the Eocene. In addition, there is a good correlation between the timing of the Eocene inversion in NW Europe and the tectonic movements observed in the North Alpine foreland basin (Blundell 2002). Although the origin of the inversion climax is poorly constrained, we consider that it could result from an increase in the horizontal principal stress in the Alpine foreland related to the closure of the Valais rifted area in the Alps at this period (Ziegler et al. 1996). This period coincides also with a fast $\left(15 \mathrm{~mm} \mathrm{a}^{-1}\right)$ migration of a low-angle external orogenic wedge front in the Alpine region (Ford et al. 1999).

Comparison of the Late Mesozoic-Tertiary tectonic evolution of the inverted regions in Central and Western Europe reveals that the occurrence of various inversion phases is not uniform throughout the inverted territories. For example, Tertiary deformation is present in the southern North Sea, the Channel region and further to the west, but is completely missing in Central and Eastern Europe (see Ziegler 1987, fig. 3-6). In addition, there seems to be an apparent westward shift of the strongest inversion phase through time, with the latest (Oligo-Miocene) inversion phase being strongest in the Channel area. These spatial fluctuations in inversion characteristics suggest that the interaction between the orogen, the foreland and other factors such as stresses originating from the opening of the North Atlantic is very complex (e.g. Ziegler et al. 1998) and the inversion in the Alpine foreland cannot be explained by a single and simple model. It was proposed that factors such as local and regional lithospheric structure, basin fill, basin geometry and geological history (amount, style and timing of basin formation, etc.) of the inverted basins should also be taken into account (e.g. Gillcrist et al. 1987; Huyghe \& Mugnier 1995).

Magnitude and other characteristics of the inversion can change not only spatially but also temporally, as demonstrated by the Late Cretaceous-Mid-Palaeocene and Late Eocene inversion phases in the West Netherlands Basin and Broad Fourteens Basin. One possible explanation could be the mechanical stabilization of the previously weakened crust during and after the first inversion phase creating a stronger lithosphere for the subsequent inversion periods ('locked system', Ziegler 1987). De Lugt et al. (2003) proposed different directions of compression during the Latest Cretaceous and the Eocene as an explanation; however, this is not supported by data for the relative motion between Africa and Europe (e.g. Lake \& Karner 1987). An alternative model is that the lithospheric strength profiles and/or the coupling between the orogen and the European foreland changed during and between these periods of inversion, leading to different stress magnitudes and different response of the lithosphere under compression (Cloetingh et al. 1999). The exact 
mechanism and cause of such fluctuations in the mechanical coupling between orogen and continent as well as the development, presence or absence of major intraplate discontinuities during the Cretaceous-Tertiary period is not yet understood and should be the subject of future studies.

\section{Conclusions}

The Eocene inversion of the West Netherlands Basin is the result of a continuous inversion process throughout the Late Palaeocene-Eocene rather than a distinct pulse at the end of the Eocene. The inversion is characterized by the continuous doming of the Early Tertiary High and is accompanied by the reactivation of pre-existing faults in a reverse mode. Beside tectonics, differential compaction also significantly contributed to the present-day thinning and tilted state of the Eocene sediments. The intensity of the tectonic movements was not uniform throughout the Eocene: they were much stronger during the Latest Eocene (Pyrenean inversion phase) than during the Early and Mid-Eocene. A good correlation was found between Alpine tectonic events and the Eocene inversion of the West Netherlands Basin. In light of this and the inversion characteristics revealed by this study, the Latest Eocene inversion pulse in the West Netherlands Basin can be considered as the culmination of a continuous inversion process that originated from the Alpine collision. The feature of continuous tectonic movements culminating in a stronger inversion phase seems to be a general characteristic of the Palaeogene inversion in NW Europe, as the same feature was found in other southern North Sea basins (e.g. Broad Fourteens Basin) and, although with different timing, in the English Channel area as well as in Central Belgium.

Based on a geometric approach and on the interval velocity and bulk density analysis of Lower Palaeogene sediments it is estimated that c. $250-450 \mathrm{~m}$ of Palaeogene sediments were removed from the rim of the Early Tertiary High during the inversion. This amount of erosion is of the same order of magnitude as in other basins in the southern North Sea region.

This study was carried out in co-operation between the Vrije Universiteit, Amsterdam (VUA) and the TNO-NITG (Dutch Geological Survey, Utrecht). The authors thank H. Pagnier (TNO-NITG) and S. Cloetingh (VUA) for making this study possible. We are also grateful to P. Ziegler for fruitful discussion in the early phase of this study, and to R. J. van Leeuwen for the biostratigraphic age determination. The comments of $\mathrm{R}$. T. van Balen, R. Lisle and J. Underhill, which significantly contributed to the improvement of the paper, are also appreciated.

\section{References}

Blundell, D.J. 2002. Cenozoic inversion and uplift of southern Britain. In: DoRÉ, A.G., Cartwright, J.A., Stoker, M.S., Turner, J.P. \& White, N. (eds) Exhumation of the North Atlantic Margin: Timing, Mechanisms and Implications for Petroleum Exploration. Geological Society, London, Special Publications, 196, 85-101.

Cameron, T.D.J., Crosby, A., Balson, P.S., Jeffery, D.H., Lott, G.K., Bulat, J. \& Harrison, D.J. 1992. United Kingdom Offshore Regional Report: the Geology of the Southern North Sea. HMSO for the British Geological Survey, London.

Chadwick, R.A. 1985. Cenozoic sedimentation, subsidence and tectonic inversion. In: Whittaker, A. (ed.) Atlas of Onshore Sedimentary Basins in England and Wales; Post-Carboniferous Tectonics and Stratigraphy. Blackie, Glasgow, $61-63$.

CHADwick, R.A. 1993. Aspects of basin inversion in southern Britain. Journal of the Geological Society, London, 150, 311-322.

Cloetingh, S., Burov, E. \& Poliakov, A. 1999. Lithosphere folding: primary response to compression? (from central Asia to Paris basin). Tectonics, 18, 1064-1083.

Curry, D. 1992. Tertiary. In: Duff, P.M.D. \& Sмith, A.J. (eds) Geology of
England and Wales. Geological Society, London, 389-408.

DAley, B. \& EdWARds, N. 1971. Palaeogene warping in the Isle of Wight. Geological Magazine, 108(5), 399-405.

De Batist, M. \& Henriet, J.P. 1995. Seismic stratigraphy of the Palaeogene offshore of Belgium, southern North Sea. Journal of the Geological Society, London, 152, 27-40.

De Batist, M. \& Versteeg, W.H. 1999. Seismic stratigraphy of the Mesozoic and Cenozoic in northern Belgium: main results of a high-resolution reflection seismic survey along rivers and canals. Geologie en Mijnbouw, 77, 17-37.

De Jager, J., Doyle, M.A., Grantham, P.J. \& Mabillard, J.E. 1996. Hydrocarbon habitat of the West Netherlands Basin. In: RondeEL, H.E., Batjes, D.A.J. \& Nieuwenhuis, W.H. (eds) Geology of Gas and Oil under the Netherlands. Royal Geological and Mining Society of the Netherlands (KNGMG), Kluwer Academic, Dordrecht, 191-209.

De Lugt, I.R., Van Wees, J.D. \& Wong, Th.E. 2003. The tectonic evolution of the southern Dutch North Sea during the Palaeogene: basin inversion in distinct pulses. Tectonophysics, 373(1-4), 141-159.

Dronkers, A.J. \& Mrozek, F.J. 1991. Inverted basins of the Netherlands. First Break, 9(9), 409-425.

FABRICIUS, I.L. 2003. How burial diagenesis of chalk sediments controls sonic velocity and porosity. AAPG Bulletin, 87(11), 1755-1778.

FORD, M., LICKORISH, W.H. \& KUSZNIR, N.J. 1999. Tertiary foreland sedimentation in the Southern Subalpine Chains, SE France: a geodynamic appraisal. Basin Research, 11, 315-336.

Gale, A.S., Jeffery, P.A., Huggett, J.M. \& Conolly, P. 1999. Eocene inversion history of the Sandown Pericline, Isle of Wight, southern England. Journal of the Geological Society, London, 156, 327-339.

Gillcrist, R., Coward, M.P. \& Mugnier, J.L. 1987. Structural inversion and its controls: examples from the Alpine foreland and the French Alps. Geodinamica Acta, 1(1), 5-34.

Gölke, M. \& CoblentZ, D. 1996. Origins of the European regional stress field. Tectonophysics, 266, 11-24.

Gras, R. \& Geluk, M.C. 1999. Late Cretaceous-Early Tertiary sedimentation and tectonic inversion in the southern Netherlands. Geologie en Mijnbouw, 78, $1-19$.

Grüztner, J. \& Mienert, J. 1999. Physical property changes as a monitor of pelagic carbonate diagenesis: an empirically derived diagenetic model for the Atlantic Ocean basins. AAPG Bulletin, 83, 1485-1501.

Heybroek, P. 1974. Explanation to tectonic maps of the Netherlands. Geologie en Mijnbouw, 53(2), 43-50.

HiLlis, R.R. 1993. Quantifying erosion in sedimentary basins from sonic velocity in shales and sandstones. Exploration Geophysics, 24, 561-566.

Huyghe, P. \& Mugnier, J.L. 1995. A comparison of inverted basins of the southern North Sea and inverted structures of the external Alps. In: Buchanan, J.G. \& Buchanan, P.G. (eds) Basin Inversion. Geological Society, London, Special Publications, 88, 339-353.

IsaAc, K.P. \& Plint, A.G. 1983. Discussion on Eocene sedimentation and tectonics in the Hampshire Basin and reply. Journal of the Geological Society, London, 140(2), 319-320.

JAPSEN, P. 1998. Regional velocity-depth anomalies, North Sea Chalk; a record of overpressure and Neogene uplift and erosion. AAPG Bulletin, 82(11), 2031-2074.

JAPSEN, P. 2000. Investigation of multi-phase erosion using reconstructed shale trends based on sonic data; Sole Pit axis, North Sea. Global and Planetary Change, 24(3-4), 189-210.

Jones, D.K.C. 1980. The Tertiary evolution of south-east England with particular reference to the Weald. In: JonES, D.K.C. (ed.) The Shaping of Southern England. Institute of British Geographers, Special Publication, 11, 13-47.

Jones, M.E., BedFord, J. \& Clayton, C.J. 1984. On natural deformation mechanisms in the chalk. Journal of the Geological Society, London, 141, $675-683$.

LAKE, S.D. \& KARNER, G.D. 1987. The structure and the evolution of the Wessex Basin, southern England: an example of inversion tectonics. Tectonophysics, 137, 347-378.

Letsch, W.J. \& Sissingh, W. 1983. Tertiary stratigraphy of The Netherlands. Geologie en Mijnbouw, 62, 305-318.

Mallon, A.J. \& Swarbrick, R.E. 2002. A compaction trend for non-reservoir North Sea Chalk. Marine and Pertoleum Geology, 19(5), 527-539.

Michon, L., Van Balen, R.T., Merle, O. \& Pagnier, H. 2003. The Cenozoic evolution of the Roer Valley Rift System integrated at a European scale. Tectonophysics, 367, 101-126.

Monié, P. \& Philippot, P. 1989. Mise en évidence de l'âge Eocène moyen du métamorphisme de haute-pression dans la nappe ophiolitique du Mont Viso (Alpes occidentales) par la méthode ${ }^{39} \mathrm{Ar}-{ }^{40} \mathrm{Ar}$. Comptes Rendus de l'Académie des Sciences, 309, 245-251.

Nalpas, T., Le Douaran, S., Brun, J.P., Unternehr, P. \& Richert, J.P. 1995. Inversion of the Broad Fourteens Basin (offshore Netherlands), a small-scale model investigation. Sedimentary Geology, 95, 237-250. 
Pettijohn, F.J. 1984. Sedimentary Rocks, 3rd. CBS, Delhi.

Plint, A.G. 1982. Eocene sedimentation and tectonics in the Hampshire Basin. Journal of the Geological Society, London, 139, 249-254.

Racero-Baena, A. \& Drake, S.J. 1996. Structural style and reservoir development in the West Netherlands oil province. In: RondeEl, H.E., BatJes, D.A.J. \& Nieuwenhuiss, W.H. (eds) Geology of Gas and Oil under the Netherlands. Royal Geological and Mining Society of the Netherlands (KNGMG), Kluwer Academic, Dordrecht, 211-227.

Sclater, J.G. \& Christie, P.A.F. 1980. Continental stretching: an explanation of post-mid-Cretaceous subsidence of the central North Sea Basin. Journal of Geophysical Research, 85(B7), 3711-3739.

Small, R.J. 1980. The Tertiary geomorphological evolution of south-east England: an alternative interpretation. In: Jones, D.K.C. (ed.) The Shaping of Southern England. Institute of British Geographers, Special Publications, 11, 49-70.

Talwani, M. \& Eldholm, O. 1977. Evolution of the Norwegian-Greenland sea. Geological Society of America Bulletin, 88(7), 969-999.

Tilton, G.R., Schreyer, W. \& Schertl, H.P. 1991. Pb-Sr-Nd isotopic behavior of deeply subducted crustal rocks from the Dora Maira Massif, Western Alps, Italy: II. What is the age of the ultrahigh-pressure metamorphism? Contributions to Mineralogy and Petrology, 108, 22-33.

TNO-NITG 2002. Geological Atlas of the Subsurface of the Netherlands: Explanation to Mapsheets VII and VIII: Noordwijk-Rotterdam and Amsterdam-Gorinchem. TNO-NITG, Utrecht.

Underhill, J.R. \& PAterson, S. 1998. Genesis of tectonic inversion structures: seismic evidence for the development of key structures along the PurbeckIsle of Wight Disturbance. Journal of the Geological Society, London, 155, 975-992.

VÅgnes, E., Gabrielsen, R.H. \& Haremo, P. 1998. Late Cretaceous-Cenozoic intraplate contractional deformation at the Norwegian continental shelf: timing, magnitude and regional implications. Tectonophysics, 300, 29-46.
Van Adrichem Boogaert, H.A. \& Kouwe, W.F.P. 1997. Stratigraphic Nomenclature of The Netherlands, Revision and Update by RGD and NOGEPA. Mededelingen Rijks Geologische Dienst, Haarlem.

Vandenberghe, N., Laga, P., Steurbaut, E., Hardenbol, J. \& Vail, P.R. 1998. Tertiary sequence stratigraphy at the southern border of the North Sea Basin in Belgium. In: De Graciansky, P.C., Hardenbol, J., Jacquin, T. \& VAIL, P.R. (eds) Mesozoic and Cenozoic Sequence Stratigraphy of European Basins. SEPM Special Publications, 60, 119-154.

VAN Hoorn, B. 1987. Structural evolution, timing and tectonic style of the Sole Pit inversion. Tectonophysics, 137, 239-284.

Van WiJhe, D.H. 1987. Structural evolution of inverted basins in the Dutch offshore. Tectonophysics, 137, 171-219.

Wooldridge, S.W. \& Linton, D.L. 1955. Structure, Surface and Drainage in South-East England. George Philip, London.

ZAGWIJN, W.H. 1989. The Netherlands during the Tertiary and the Quaternary: a case history of Coastal Lowland evolution. Geologie en Mijnbouw, 68, $107-120$.

Ziegler, P.A. 1987. Late Cretaceous and Cenozoic intra-plate compressional deformations in the Alpine foreland - a geodynamic model. Tectonophysics, 137, 389-420.

Ziegler, P.A. 1990. Geological Atlas of Western and Central Europe, 2nd. Shell, The Hague.

Ziegler, P.A., Schmid, S.M., Pfiffner, A. \& Schönborn, G. 1996. Structure and evolution of the Central Alps and their northern and southern foreland basins. In: Ziegler, P.A. \& Horvath, F. (eds) Peri-Tethys Memoir 2: Structure and Prospects of Alpine Basins and Forelands. Mémoires du Muséum National d'Histoire Naturelle, 170, 211-233.

Ziegler, P.A., Van Wees, J.D. \& Cloetingh, S. 1998. Mechanical controls on collision-related compressional intraplate deformation. Tectonophysics, $\mathbf{3 0 0}$, 103-129. 